\title{
PEMAHAMAN KONSEP GRAFIK FUNGSI KUADRAT SISWA KELAS X SMA
}

\author{
Ibnu Sina Fauzi ${ }^{1}$, Erlina Prihatnani ${ }^{2}$ \\ ${ }^{1,2}$ Program Studi Pendidikan Matematika, FKIP, Universitas Kristen Satya Wacana, J1. Diponegoro No. 52-60, Salatiga \\ 202016042@student.uksw.edu
}

\begin{abstract}
Comprehending a concept is needed to make students able to solve an issue in mathematics. Not all the students have the same level in comprehending a concept in mathematics. In consequence, this study aims to analyze the tenth grade of Senior High School students' comprehension about the concept of the graphs of a quadratic function. The subjects of this study are the tenth grade of Senior High School students by using the Purposive Sampling technique. The data in this study were collected by using tests and non-structured interviews. The indicators of concept comprehension are (1) restating a concept; (2) classifying objects according to certain characteristics which is suitable with the concept; (3) giving the right and wrong examples of a concept; (4) providing a concept in a form of various mathematical representations; (5) developing necessary specifications or sufficient specifications from a concept; (6) using, utilizing, and choosing certain procedures or operations; (7) applying the algorithm concept into a problem-solving. The result of this study shows that each student has a different level in comprehending a concept. The level of concept comprehension affects student success in mathematics solving problems. According to the result, teachers are suggested to push a concept comprehension before training a mathematics problem solving to students.
\end{abstract}

Keywords: ConceptUnderstanding, Graphs of Quadratic Funtions, Tenth Grade of Senior High School Students.

\section{Abstrak}

Pemahaman konsep diperlukan agar siswa dapat menyelesaikan permasalahan yang ada dalam matematika. Tidak setiap siswa memiliki pemahaman yang sama akan suatu konsep dalam matematika. Oleh karena itu, penelitian ini bertujuan untuk melakukan analisis terhadap pemahaman konsep grafik fungsi kuadrat terhadap siswa kelas X SMA. Subjek penelitian ini adalah siswa kelas X SMA dengan menggunakan teknik Purposive Sampling. Data dikumpulkan melalui tes dan wawancara non-terstruktur. Indikator pemahaman konsep meliputi (1) menyatakan ulang sebuah konsep; (2) mengklasifikasikan objek menurut sifat-sifat tertentu sesuai dengan konsepnya; (3) memberikan contoh dan bukan contoh dari suatu konsep; (4) menyajikan konsep dalam berbagai bentuk representasi matematis; (5) mengembangkan syarat perlu atau syarat cukup dari suatu konsep; (6) menggunakan dan memanfaatkan serta memilih prosedur atau operasi tertentu; (7) mengaplikasikan konsep algoritma pada pemecahan masalah. Hasil penelitian menunjukkan bahwa setiap siswa memiliki pemahaman konsep yang berbeda. Tingkat pemahaman konsep mempengaruhi keberhasilan siswa dalam menyelesaikan permasalahan matematika. Berdasarkan hasil tersebut, maka disarankan bagi guru untuk menekankan pemahaman konsep sebelum pemberian pelatihan pemecahan masalah matematika.

Kata kunci :Pemahaman Konsep, Grafik Fungsi Kuadrat, Siswa Kelas X SMA.

Pada pembelajaran matematika, siswa diharapkan mampu mempelajari seluruh objek dalam matematika. Gagne (Shadiq, 2011; 10) membagi objek-objek matematika menjadi 4 hal yaitu fakta (fact), konsep (concept), prinsip (principle), dan keterampilan (skill). Fakta adalah konvensi (kesepakatan) dalam matematika seperti lambang, notasi, ataupun aturan seperti $5+2 \times 10=5+$ 20, di mana operasi perkalian didahulukan dari operasi penjumlahan. Konsep adalah suatu ide abstrak yang memungkinkan seseorang untuk mengklasifikasikan suatu objek dan menjelaskan apakah objek tersebut merupakan contoh dan bukan contoh dari ide abstrak tersebut. Contoh konsep bilangan rasional sebagai bilangan yang dapat dinyatakan dalam bentuk $\frac{a}{b}$ dengan $a$ dan $b$ merupakan bilangan real. Berdasarkan konsep tersebut diketahui bahwa 0,25 atau $\left(\frac{1}{4}\right)$ merupakan bilangan rasional, sedangkan $\sqrt{2}$ bukan merupakan bilangan rasional. Prinsip adalah suatu pernyataan yang memuat 
hubungan antara dua konsep atau lebih. Contoh yaitu rumus luas segitiga $L=\frac{1}{2} \times$ alas $\times$ tinggi. Pada rumus luas segitiga didapati adanya beberapa konsep yang digunakan, yaitu konsep luas, konsep panjang alas segitiga dan konsep tinggi segitiga. Adapun keterampilan adalah suatu prosedur atau aturan untuk mendapatkan atau memperoleh suatu hasil. Contohnya adalah keterampilan untuk menentukan luas segitiga jika diketahui panjang alas dan tinggi segitiga.

Menurut Idris (2009), pemahaman konsep bukan hanya sekedar mengingat konsep atau mengikuti prosedur untuk menyelesaikan soal, melainkan kemampuan untuk dapat menjelaskan, menemukan bukti, memberi contoh dan bukan contoh, menggeneralisasikan, dan merepresentasikan konsep. Zirbel (2006) berpendapat bahwa pemahaman konsep berarti konsep-konsep yang direpresentasikan dan dihubungkan dengan baik. Artinya pemahaman melibatkan beberapa konsep dalam satu kesatuan yang tiap-tiap konsepnya memiliki makna masing-masing.

Penguasaan pemahaman konsep matematika merupakan hal yang penting dalam pembelajaran matematika, karena dengan pemahaman tersebut akan memudahkan siswa dalam mempelajari matematika dan menyelesaikan permasalahan yang ada. Zulkardi (2003:7) menyampaikan bahwa matematika merupakan mata pelajaran yang menekankan pada konsep yang berarti bahwa dalam dalam belajar matematika jika siswa ingin dapat menyelesaikan soal-soal dan mampu mengaplikasikannya dalam dunia nyata maka terlebih dahulu harus memahami konsep matematika.

Pemahaman konsep matematika yang diteliti dalam penelitian ini merupakan indikator pemahaman konsep matematika (Kusumawati, 2010: 28-29). Adapun indikator pemahaman konsep matematika, yaitu: (1) menyatakan ulang sebuah konsep; (2) mengklasifikasikan objek menurut sifatsifat tertentu sesuai dengan konsepnya; (3) memberikan contoh dan bukan contoh dari suatu konsep; (4) menyajikan konsep dalam berbagai bentuk representasi matematis; (5) mengembangkan syarat perlu atau syarat cukup dari suatu konsep; (6) menggunakan dan memanfaatkan serta memilih prosedur atau operasi tertentu; (7) mengaplikasikan konsep algoritma pada pemecahan masalah. Indikator pemahaman konsep matematika ini digunakan karena pada Standar Isi (SI) mata pelajaran matematika untuk satuan pendidikan dasar dan menengah (dikdasmen) dimuat uraian dan ketentuan tentang latar belakang, tujuan, ruang lingkup, serta daftar Standar Kompetensi (SK) dan Kompetensi Dasar (KD) yang harus dikuasai siswa pada pelajaran matematika. Salah satu tujuan pembelajaran matematika yang dipaparkan diantaranya yaitu, siswa diharapkan memahami konsep matematika yang diukur menggunakan indikator pemahaman konsep matematika tersebut.

Indikasi kurangnya pemahaman konsep dialami oleh siswa kelas X (sepuluh) SMA Negeri 1 Ambarawa pada materi Fungsi Kuadrat. Dalam wawancara, guru menyebutkan bahwa siswa masih mengalami kesulitan dalam menggambar grafik Fungsi Kuarat. Berawal dari keterangan tersebut, maka dilakukan studi pendahuluan dengan memberikan soal kepada siswa SMA Negeri 1 Ambarawa kelas X (Sepuluh). Soal dapat dilihat pada Gambar 1. Terdapat tiga jenis subjek yang memberikan respon berbeda, yaitu subjek yang mampu menyelesaikan soal dengan benar (Subjek 1), subjek yang 
mampu membuat sketsa grafik dengan benar namun tidak bisa menyelesaikan soal (Subjek 2), dan subjek yang sama sekali tidak mampu mengerjakan soal (Subjek 3).

Dua buah parabola mempunyai titik puncak yang sama. Parabola pertama memotong sumbu $x$ di titik $(a, 0)$ dan $(b, 0)$ serta memotong sumbu $y$ di titik $(0,-32)$. Parabola kedua definit positif dan memotong sumbu $y$ di titik $(0,40)$. Jika $a$ dan $b$ adalah dua bilangan bulat positif pertama yang habis dibagi 4. Maka, tentukan :

a. Apakah unsur-unsur yang diketahui sudah dapat untuk menentukan persamaan parabola yang kedua? Mengapa?

b. Jika sudah tentukan persamaan parabola yang kedua!

Gambar 1. Soal pemecahan masalah terkait pemahaman konsep menggambar grafik fungsi kuadrat.

Subjek 1 mampu merepresentasikan soal ke dalam sketsa grafik pada Gambar 2 dan mampu menggunakan informasi-informasi disoal untuk menemukan jawaban. Representasi Subjek 1 dan langkah-langkah penyelesaian terhadap soal pada Gambar 3. Seperti halnya Subjek 1, Subjek 2 juga mampu membuat sketsa dari soal yang diberikan. Sketsa Subjek 2 dapat dilihat pada Gambar 4. Meskipun demikian Subjek 2 tidak dapat menggunakan hal-hal yang diketahui untuk menyelesaikan soal tersebut. Sketsa berbeda diberikan Subjek 3. Sketsa ini bisa dilihat pada Gambar 5. Tampak bahwa sketsa Subjek 3 tidak tepat, karena subjek tidak menggambarkan grafik fungsi kuadrat melainkan grafik fungsi linear. Selain itu, Subjek 3 juga sama sekali tidak memberikan jawaban langkah penyelesaian.

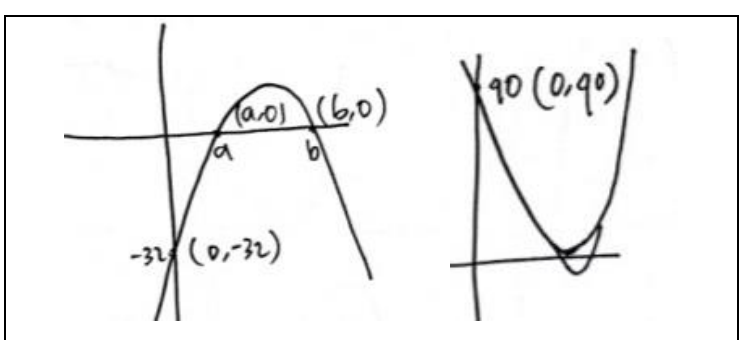

Gambar 2. Representasi subjek 1 terhadap soal yang diberikan.

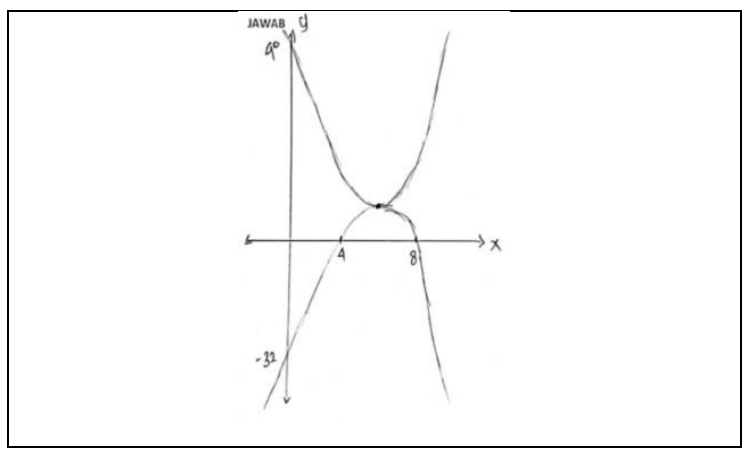

Gambar 4. Representasi subjek 2 terhadap soal yang diberikan.

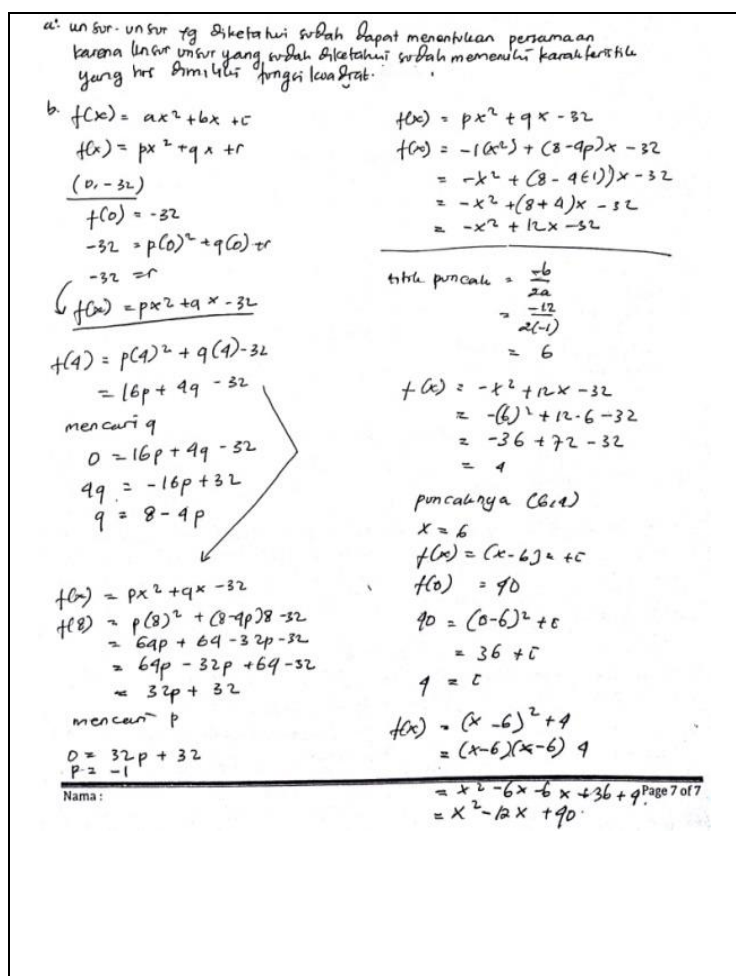

Gambar 3. Hasil pekerjaan subjek 1 terhadap soal yang diberikan. 


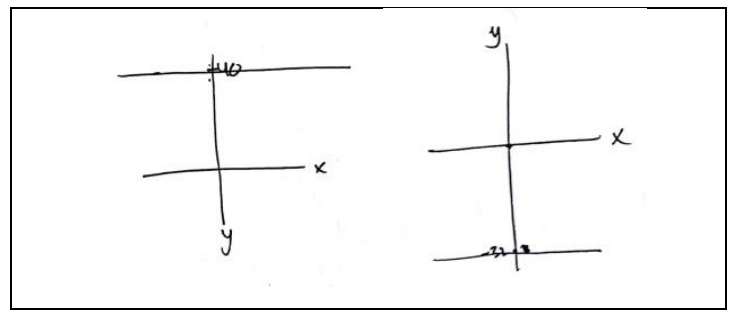

Gambar 5. Representasi subjek 3 terhadap

soal yang diberikan.

Tidak semua siswa dapat menyelesaikan soal tersebut menggunakan pemahaman konsep grafik fungsi kuadrat secara benar. Hal ini sejalan dengan Suraji et al. (2018) yang mengemukakan bahwa kemampuan pemahaman konsep metematis dalam merepresentasikan konsep sulit dan kurang antusias. Hal ini mengindikasikan adanya perbedaan tingkat pemahaman siswa. Oleh karena itu, dilakukannya penelitian lebih lanjut untuk mengetahui pemahaman konsep ketiga jenis subjek tersebut terhadap konsep grafik fungsi kuadrat dengan menggunakan 7 indikator pemahaman konsep dalam (Kusumawati, 2010: 28-29).

Terdapat beberapa penelitian terdahulu yang telah mendeskripsikan pemahaman siswa akan konsep dalam matematika, diantaranya penelitian Fitriastika (2014), Kadir (2018) dan Ayu (2018), berturut-turut pada konsep Fungsi Kuadrat pada siswa kelas X, Segi Empat pada siswa kelas VII, dan Faktorisasi Suku Aljabar pada siswa kelas VIII. Hasil dari ketiga penelitian tersebut menunjukkan bahwa pemahaman konsep setiap siswa sangatlah berbeda-beda. Contoh penelitian Fitriastika (2014) pada Fungsi Kuadrat menggunakan teori APOS. Hasil penelitian ini menunjukkan bahwa keempat subjek tidak memiliki struktur pada pemahaman tahap objek, hal ini dikarenakan subjek masih menemukan kesulitan untuk memahami soal. Seperti halnya pada ketiga penelitian tersebut, penelitian ini juga mendeskripsikan pemahaman konsep siswa berdasarkan berhasil atau tidaknya siswa dalam menyelesaikan permasalahan pada Gambar 1.

Hasil analisis diharapkan dapat memberikan gambaran secara detail akan konsep-konsep yang telah dipahami dan yang belum dipahami siswa terhadap grafik Fungsi Kuadrat. Informasi ini diharapkan dapat dijadikan pedoman bagi guru dalam mengajarkan Fungsi Kuadrat. Misalnya dalam menentukan konsep-konsep apa saja yang harus diberi penekanan. Selain itu, guru juga dapat mendesain suatu skema pembelajaran yang dapat memfasilitasi siswa untuk mengkontruksikan konsep-konsep yang biasanya tidak/belum dikuasai siswa. Hal ini selaras dengan Mustofa \& Tuharto (2018), bahwa pemahaman konsep dapat meningkat dengan mengimplementasikan model pembelajaran. 


\section{METODE}

Penelitian ini merupakan penelitian kualitatif deskriptif yang dilakukan terhadap siswa kelas X SMA Negeri 1 Ambarawa yang telah mempelajari materi Fungsi Kuadrat. Menurut Hanifah (2018), penelitian kualitatif deskriptif merupakan suatu penelitian ilmiah yang bertujuan untuk memahami suatu fenomena tentang apa yang dialami subjek penelitian. Pada penelitian ini, peneliti akan memaparkan pemahaman konsep siswa kelas X SMA Negeri 1 Ambarawa tahun 2018-2019.

Subjek dalam penelitian ini dipilih berdasarkan berhasil atau tidaknya subjek dalam menyelesaikan soal pada Gambar 1. Berdasarkan hasil studi pendahuluan diperoleh tiga jenis subjek, yaitu: (1) Subjek yang mampu merepresentasikan soal ke dalam sketsa grafik fungsi kuadrat dan mampu menggunakan informasi-informasi pada soal untuk menyelesaikan permasalahan, (2) Subjek yang mampu membuat sketsa grafik fungsi kuadrat, namun tidak dapat menyelesaikan soal, dan (3) Subjek yang tidak berhasil menggambarkan sketsa grafik fungsi kuadrat dan tidak dapat menyelesaikan soal.

Pengumpulan data dilakukan dengan metode tes dan metode wawancara sedangkan instrumen dalam penelitian ini adalah 6 soal yang dapat digunakan untuk mengukur ke tujuh indikator pemahaman akan konsep grafik fungsi kuadrat. Analisis penelitian ini berupa deskripsi pemahaman konsep grafik fungsi kuadratdari ketiga jenis subjek tersebut. Hasil analisis ini menginformasikan pemahaman konseptual siswa kelas X (Sepuluh) SMA Negeri 1 Ambarawa terhadap konsep grafik fungsi kuadrat, berdasarkan indikator pemahaman konsep matematika (Kesumawati, 2010: 28-29) diantaranya: (1) menyatakan ulang sebuah konsep; (2) mengklasifikasikan objek menurut sifat-sifat tertentu sesuai dengan konsepnya; (3) memberikan contoh dan bukan contoh dari suatu konsep; (4) menyajikan konsep dalam berbagai bentuk representasi matematis; (5) mengembangkan syarat perlu atau syarat cukup dari suatu konsep; (6) menggunakan dan memanfaatkan serta memilih prosedur atau operasi tertentu; (7) mengaplikasikan konsep algoritma pada pemecahan masalah.

HASIL

Hasil dari penelitian analisis pemahaman konsep grafik fungsi kuadrat dari ketiga jenis subjek yang memberikan respon berbeda untuk soal pada Gambar 1:

\section{Subjek 1}

\section{Menyatakan ulang sebuah konsep}

Subjek mampu menyebutkan bentuk umum fungsi kuadrat yaitu $y=a x^{2}+b x+c$. Meski demikian, subjek tidak menekankan syarat khusus fungsi kuadrat yaitu $a \neq 0$ atau pangkat tertinggi bagi variabel $x$ adalah dua. Subjek juga menyebutkan bahwa bentuk grafik fungsi kuadrat adalah parabola. Subjek mampu menyebutkan karakteristik dari grafik fungsi kuadrat, diantaranya jika $a>0$ maka grafik akan membuka ke atas, jika $a<0$ maka grafik akan membuka ke bawah, jika $c>0$ maka grafik fungsi kuadrat akan memotong sumbu $y$ positif, jika $c<0$ maka grafik akan memotong sumbu $y$ negatif, jika $c=0$ maka grafik akan memotong sumbu $y$ dititik 0 , jika $D>0$ maka grafik 
akan memotong sumbu $x$ di dua titik, jika $D=0$ maka grafik akan memotong sumbu $x$ di satu titik atau menyinggung, dan jika $D<0$ maka gafik tidak akan memotong sumbu $x$. Subjek pun mampu menyebutkan titik ekstrim $\left(X_{e}, Y_{e}\right)=\left(-\frac{b}{2 a},-\frac{D}{4 a}\right)$ dengan $X_{e}$ merupakan sumbu simetri dan $Y_{e}$ nilai ekstrim (nilai stasioner).

Berdasarkan hal tersebut dapat disimpulkan bahwa subjek 1 mampu menyatakan ulang sebuah konsep grafik fungsi kuadrat. Subjek menyatakan ulang konsep grafik fungsi kuadrat dengan menyebutkan cara mendapatkan grafik fungsi kuadrat. Subjek juga mampu menyebutkan setiap karakteristik grafik fungsi kuadrat berdasarkan nilai $a, b, c$ dan diskriminan.

\section{Mengklasifikasikan objek menurut sifat-sifat tertentu sesuai dengan konsepnya}

Subjek mampu mengidentifikasi sketsa yang merupakan grafik fungsi kuadrat dan bukan grafik fungsi kuadrat dengan berpedoman pada konsep bahwa grafik fungsi kuadrat berbentuk parabola. Hal ini dapat dilihat pada jawaban subjek pada Gambar 6. Berdasarkan jawaban tersebut, tampak bahwa subjek mampu mengklasifikasikan gambar $b, c, e$, dan $g$ sebagai grafik fungsi kuadrat karena tidak berbentuk parabola. Selain itu, meski gambar $d$ dan $j$ berupa parabola, namun subjek tidak mengklasifikasikan keduanya sebagai grafik fungsi kuadrat karena konsep yang subjek pahami adalah grafik fungsi kuadrat berupa parabola yang membuka ke atas atau ke bawah. Atas jawaban ini tampak bahwa subjek hanya mampu mengenal grafik fungsi kuadrat berupa $f(x)=a x^{2}+b x+c$ dan tidak mengenal grafik fungsi kuadrat berupa $f(y)=a y^{2}+b y+c$. Subjek juga mampu menyebutkan bahwa gambar pada grafik $h$ dan $l$ bukan grafik fungsi kuadrat karena meskipun grafik tersebut membuka ke atas atau ke bawah namun, grafik tersebut tidak berupa parabola.

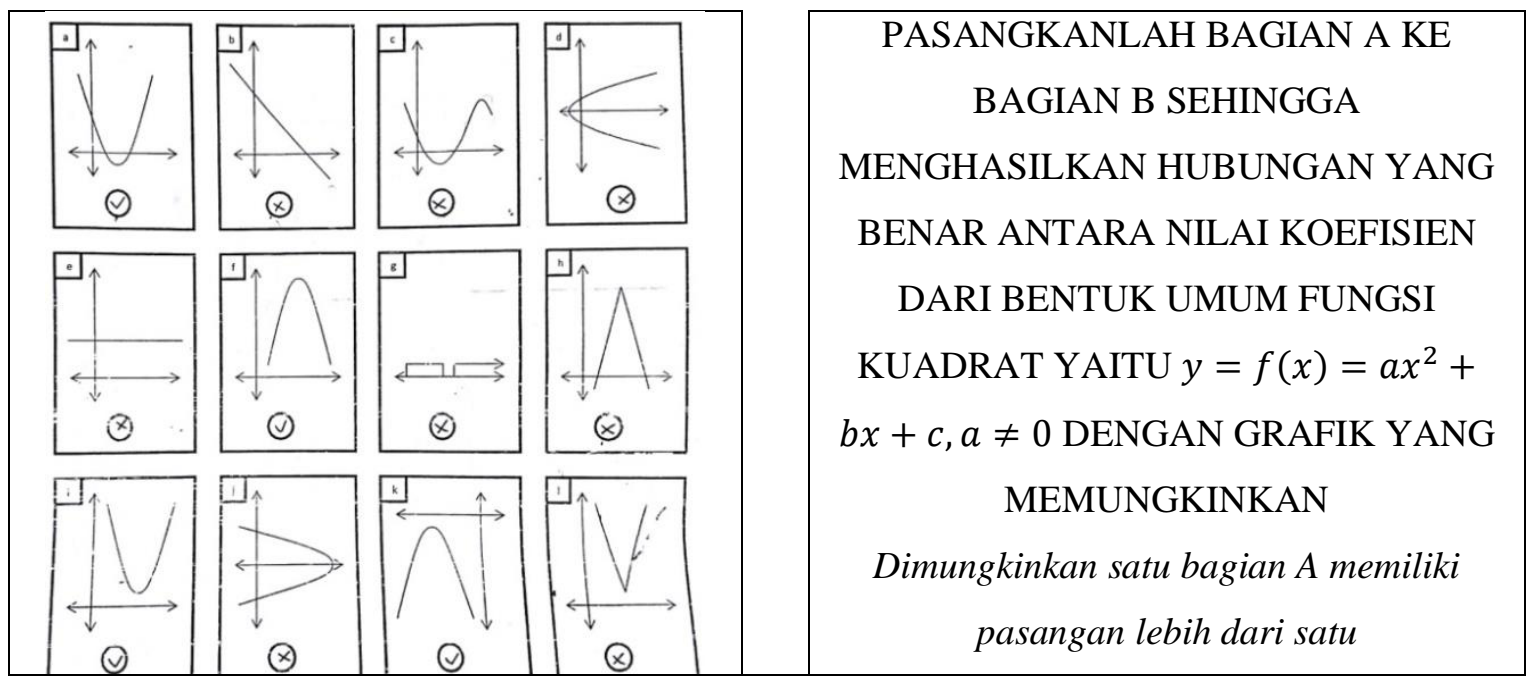




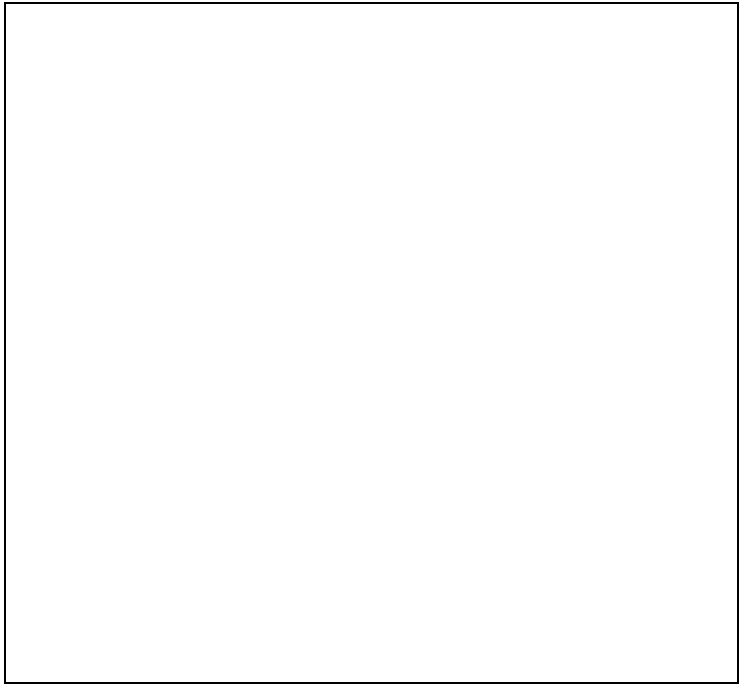

Gambar 6. Hasil identifikasi subjek akan grafik fungsi kuadrat dengan berpedoman pada bentuk parabola.

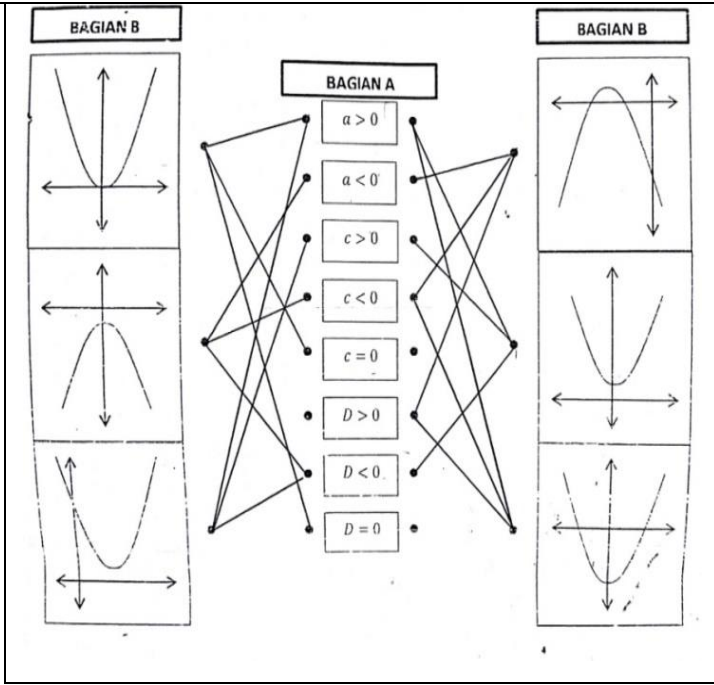

Gambar 7. Klasifikasi grafik-grafik fungsi kuadrat subjek, berdasarkan karakteristik yang disebutkan.

Tidak hanya mampu mengidentifikasi sketsa yang merupakan grafik fungsi kuadrat atau bukan, subjek juga mampu mengklasifikasikan grafik-grafik fungsi kuadrat berdasarkan karakteristik yang disebutkan. Hal ini tampak dari jawaban subjek atas soal nomor 3 yang disajikan pada Gambar 7. Berdasarkan jawaban tersebut tampak bahwa subjek mampu menunjukkan grafik fungsi kuadrat yang sesuai dengan karakteristik yang dimaksudkan yaitu nilai $a, c$, dan $D$. Tidak ada satu pun jawaban salah dari subjek. Berdasarkan hal tersebut maka dapat disimpulkan bahwa subjek mampu mengklasifikasikan grafik fungsi kuadrat baik secara umum maupun berdasarkan karakteristik tertentu.

\section{Memberikan contoh dan bukan contoh dari suatu konsep}

Selain itu, subjek juga mampu memberikan contoh dan bukan contoh dari fungsi kuadrat dan juga grafik fungsi kuadrat. Hal ini dapat dilihat dari respon siswa terhadap soal yang disajikan pada Gambar 8. Selain itu, subjek juga mampu memberikan contoh grafik fungsi kuadrat dengan kriteria khusus. Hal ini dapat dilihat pada Gambar 9. Dari 18 soal yang diberikan, subjek mampu memberikan jawaban benar sesuai dengan karakteristik fungsi kuadrat yang diberikan.

\begin{tabular}{|}
\begin{tabular}{|c|l|l|l|}
\hline 2. b) BERIKANLAH CONTOH DAN BUKAN CONTOH FUNGSI KUADRAT, DAN GAMBARKAN CONTOH YANG BUKAN \\
\hline \multirow{3}{*}{ Montoh Fungsi Kuadrat } & a) $y=4 x^{2}+7 x-29$ & b) $y=x^{2}-8 x+12$ & $\begin{array}{c}\text { Contoh Bukan Grafik Fungsi } \\
\text { Kuadrat }\end{array}$ \\
\hline & c) $y=. x^{2}-2 x-8$ & d) $y=x^{2}+x-12$ \\
\hline \multirow{3}{*}{ Contoh Bukan Fungsi Kuadrat } & a) $y=2 x-1$ & b) $y=3 x+9$ \\
\hline & c) $y=5-x$ & d) $y=6-3 x$ & \\
\hline
\end{tabular}
\end{tabular}

Gambar 8. Respon subjek ketika diminta memberikan contoh dan bukan contoh fungsi kuadrat serta menggambarkan contoh yang bukan merupakan grafik fungsi kuadrat. 


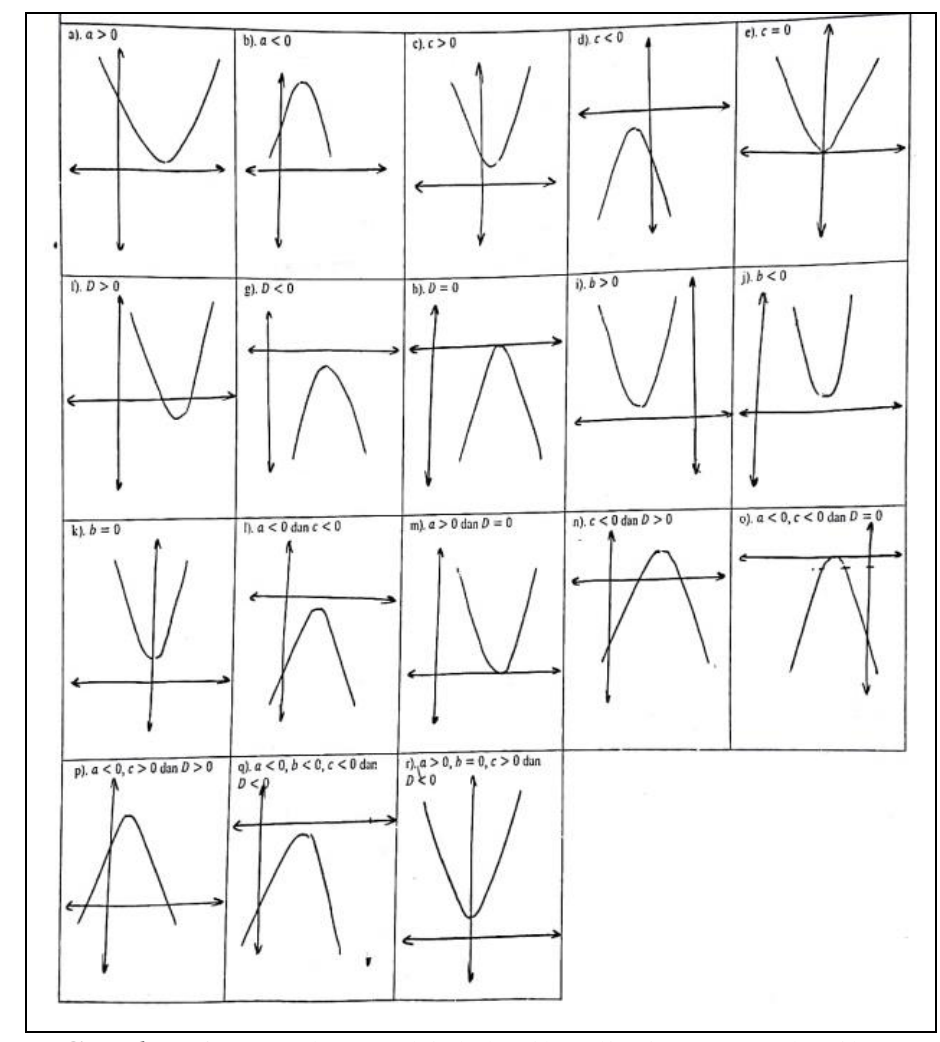

Gambar 9. Jawaban subjek ketika diminta memberikan contoh grafik fungsi kuadrat berdasarkan karakteristiknya

\section{Menyajikan Konsep Dalam Berbagai Bentuk Representasi Matematis.}

Berdasarkan uraian sebelumnya, telah tampak jelas bahwa subjek mampu menyajikan konsep grafik fungsi kuadrat ke dalam bentuk matematis. Hal ini diantaranya tampak dari: (1) Bagaimana subjek mampu menyebutkan grafik fungsi kuadrat sebagai grafik yang berasal dari fungsi $y=a x^{2}+$ $b x+c$; (2) Mampu mengidentifikasi grafik-grafik yang merupakan representasi dari fungsi kuadrat atau yang bukan fungsi kuadrat; (3) Mampu mengidentifikasi grafik fungsi kuadrat yang sesuai dengan karakteristik tertentu; (4) Mampu dalam memberikan contoh grafik fungsi kuadrat sesuai dengan karakteristik tertentu. Hal tersebut menunjukkan bahwa subjek mampu merepresentasikan grafik fungsi kuadrat ke dalam konsep kalimat, persamaan matematis dan grafik.

Selain itu, secara khusus subjek juga mampu menyajikan fungsi kuadrat tertentu ke dalam bentuk sketsa grafik fungsi kuadrat. Contoh sketsa grafik fungsi kuadrat ditunjukkan pada Gambar 10 yang merupakan jawaban subjek ketika diminta membuat sketsa grafik fungsi $y=x^{2}-6 x+11$.

Perhatikan pernyataan di bawah ini!

SOAL NOMOR 4

a. Jika diketahui persamaan $y=x^{2}-6 x+11$, apakah persamaan tersebut sudah cukup untuk menggambarkan grafik fungsi kuadrat? Mengapa demikian?

b. Jika sudah, gambarkan grafik fungsi kuadrat tersebut! 


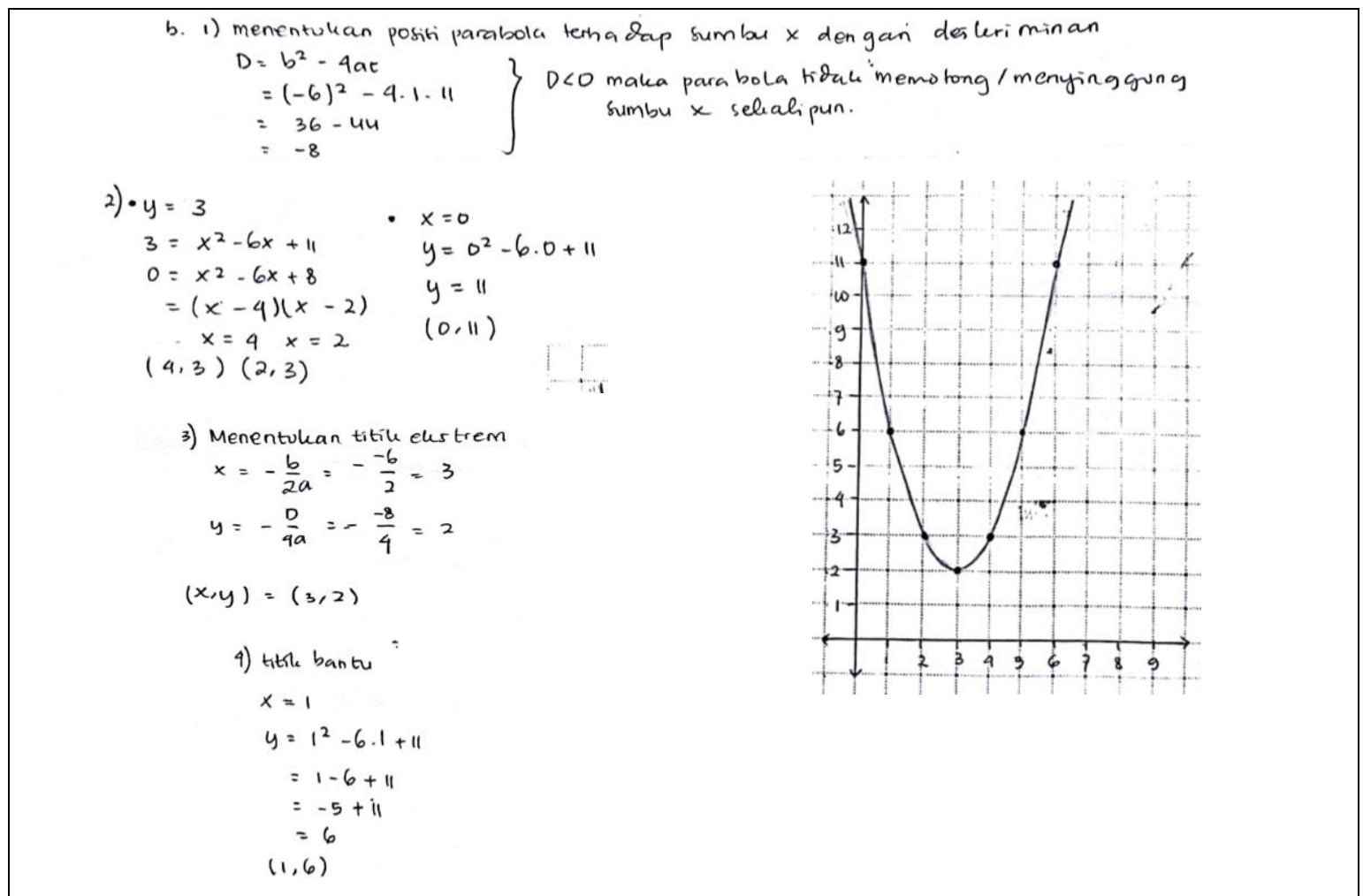

Gambar 10. Contoh sketsa grafik fungsi kuadrat dan langkah-langkah penyelesaian subjek menggambar sketsa grafik $y=x^{2}-6 x+11$

Begitu juga sebaliknya, subjek juga mampu merepresentasikan grafik fungsi kuadrat tertentu ke dalam fungsi kuadrat. Hal ini dapat dilihat dari Gambar 11 yang merupakan respon subjek dalam menentukan fungsi kuadrat dari sketsa grafik fungsi kuadrat yang diberikan.

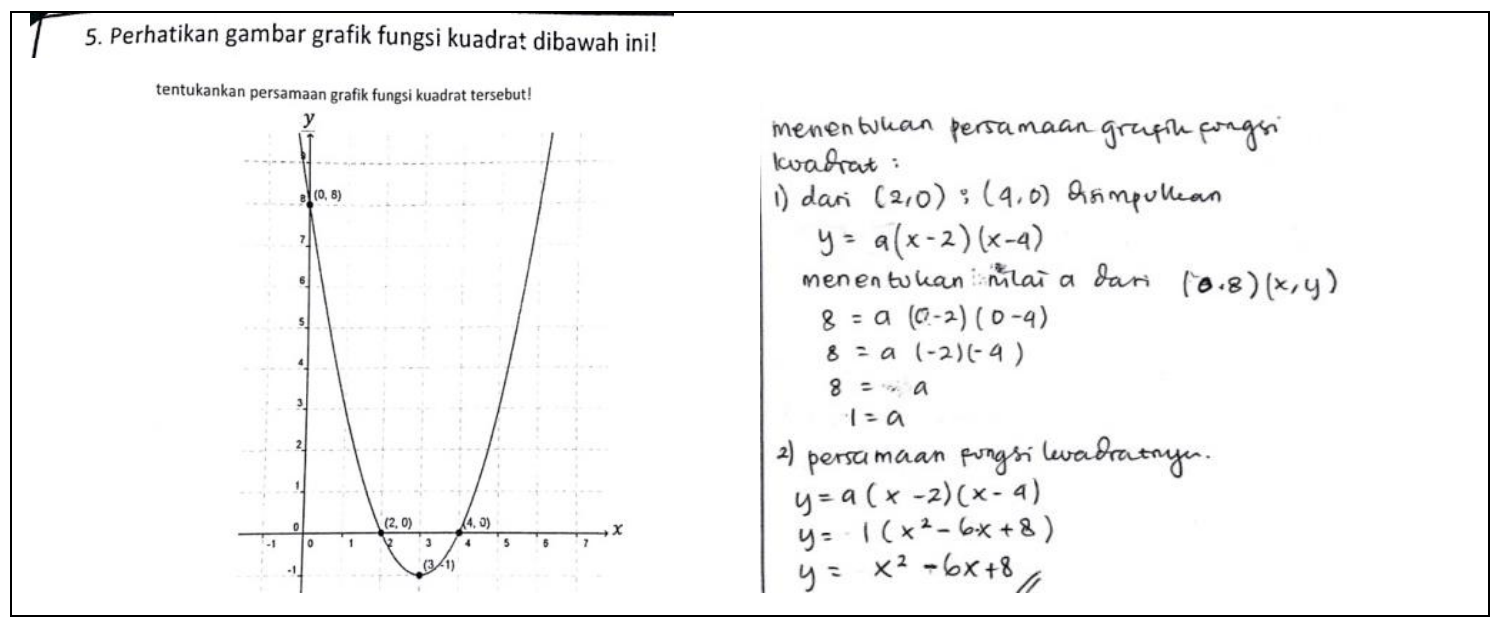

Gambar 11. Langkah-langkah dari jawaban subjek saat diminta menentukan persamaan grafik fungsi kuadrat.

\section{Mengembangkan syarat perlu atau syarat cukup dari suatu konsep.}

Dalam memahami konsep, subjek juga mampu menentukan syarat perlu dan syarat kecukupan disetiap soal yang di berikan. Contoh untuk soal nomor 4 dan 5. Subjek menyatakan bahwa informasi yang diberikan pada soal nomor 4 sudah cukup untuk digunakan dalam menyelesaikan soal. Adapun 
untuk soal nomor 5, subjek mampu menyatakan bahwa informasi-informasi pada sketsa grafik nomor 5 terlalu berlebih. Subjek menggunakan rumus jika diketahui 2 titik potong sumbu $x$ dan 1 titik lainnya yaitu $(0,8)$ sehingga titik puncak tidak diperlukan. Disisi lain, subjek menyebutkan bahwa jika akan menggunakan titik puncak dan satu titik lainnya, maka tinggal menggunakan titik $(3,-1)$ sebagai titik puncak dan memilih 1 titik lainnya.

Tidak hanya syarat cukup dengan melihat langkah-langkah penyelesaian subjek untuk soal nomor 4 (Gambar 10) dan soal nomor 5 (Gambar 11), tampak bahwa setiap langkah penyelesaian memang diperlukaan untuk menyelesaikan soal. Contoh untuk nomor 5 subjek menentukan nilai $a$ terlebih dahulu sebelum menentukan fungsi kuadrat yang dicari.

\section{Menggunakan dan memanfaatkan serta memilih prosedur atau operasi tertentu.}

Tidak hanya mengidentifikasi syarat perlu dan cukup, subjek juga mampu memilih prosedur dan menggunakan operasi yang benar dalam menyelesaikan soal. Untuk soal nomor 4 , ketika subjek diminta untuk menggambarkan grafik fungsi kuadrat pada fungsi $y=x^{2}-6 x+11$ subjek mampu: (1) Menentukan posisi parabola terhadap sumbu $x$ menggunakan diskriminan, (2) Menentukan titik potong terhadap sumbu $y$, (3) Menentukan titik puncak $\left(x_{p}, y_{p}\right)$, dan (4) Menentukan titik bantu untuk mempermudah menggambarkan sketsa grafik fungsi kuadrat.

Adapun pada soal nomor 5, sumbjek mampu: (1) Memilih prosedur, (2) Memilih unsur-unsur yang akan digunakan untuk menentukan fungsi kuadrat yaitu titik $(2,0)$ dan $(4,0)$ sebagai titik potong grafik terhadap sumbu $x$ serta titik $(0,8)$ sebagai titik potong grafik terhadap sumbu $y$, (3) Menentukan nilai $a$ dengan bantuan titik $(0,8)$, dan (4) Menentukan fungsi kuadrat dengan menggunakan rumus $y=a\left(x-x_{1}\right)\left(x-x_{2}\right)$.

Berdasarkan uraian tersebut, dapat diketahui bahwa 6 aspek terpenuhi dengan baik, sehingga untuk aspek yang ke tujuh subjek pun mampu menyelesaikannya dengan baik dan benar. Hal ini dibuktikan dengan keberhasilan subjek menyelesaikan soal pendahuluan yang mana subjek mampu mengaplikasikan konsep dan algoritma pada pemecahan masalah.

\section{Subjek 2}

\section{Menyatakan ulang sebuah konsep}

Subjek mampu menyebutkan bahwa bentuk umum dari fungsi kuadrat adalah $y=a x^{2}+$ $b x+c$, dan berbentuk kurva parabola. Subjek 2 tidak menekankan syarat khusus fungsi kuadrat yaitu $a \neq 0$ atau pangkat tertinggi bagi variabel $x$ adalah dua. Berawal dari nilai koefisien $a, b, c$ dan nilai diskriminan, subjek 2 hanya mampu menjelaskan pengertian $a$ terhadap bentuk grafik fungsi kuadrat yaitu $a>0$ maka grafik akan membuka ke atas, begitu pula sebaliknya ketika $a<0$ maka grafik akan membuka ke bawah. Sedangkan untuk nilai $b, c$ dan diskriminan subjek tidak mampu menyebutkan pengaruhnya terhadap grafik fungsi kuadrat. 
Berdasarkan hal tersebut dapat disimpulkan bahwa subjek 2 belum sepenuhnya mampu menyatakan ulang sebuah konsep grafik fungsi kuadrat. Subjek tidak dapat menyebutkan karakteristik grafik fungsi kuadrat berdasarkan nilai $b, c$ dan $D$ (diskriminan).

\section{Mengklasifikasikan objek menurut sifat-sifat tertentu sesuai dengan konsepnya.}

Subjek mampu mengidentifikasi gambar grafik fungsi kuadrat dan bukan grafik fungsi kuadrat dengan berpedoman pada konsep bahwa grafik fungsi kuadrat berbentuk parabola. Hal ini dapat dilihat pada jawaban subjek untuk soal nomor 2 yang disajikan pada Gambar 12. Subjek mampu mengidentifikasi grafik fungsi kuadrat berdasarkan bentuk grafik yang berbentuk parabola, oleh karena itu subjek mengklasifikasikan sketsa grafik yang membuka ke kanan dan ke kiri sebagai grafik fungsi kuadrat. Lain halnya ketika subjek diminta untuk mengidentifikasi yang merupakan grafik fungsi kuadrat atau bukan, subjek tidak mampu mengklasifikasikan grafik-grafik fungsi kuadrat berdasarkan karakteristik yang disebutkan. Hal ini tampak dari jawaban subjek atas soal nomor 3 yang disajikan pada Gambar 13. Berdasarkan jawaban tersebut tampak bahwa subjek tidak mampu menunjukkan grafik fungsi kuadrat yang sesuai dengan karakteristik yang dimaksud, yaitu nilai $c$ dan $D$.

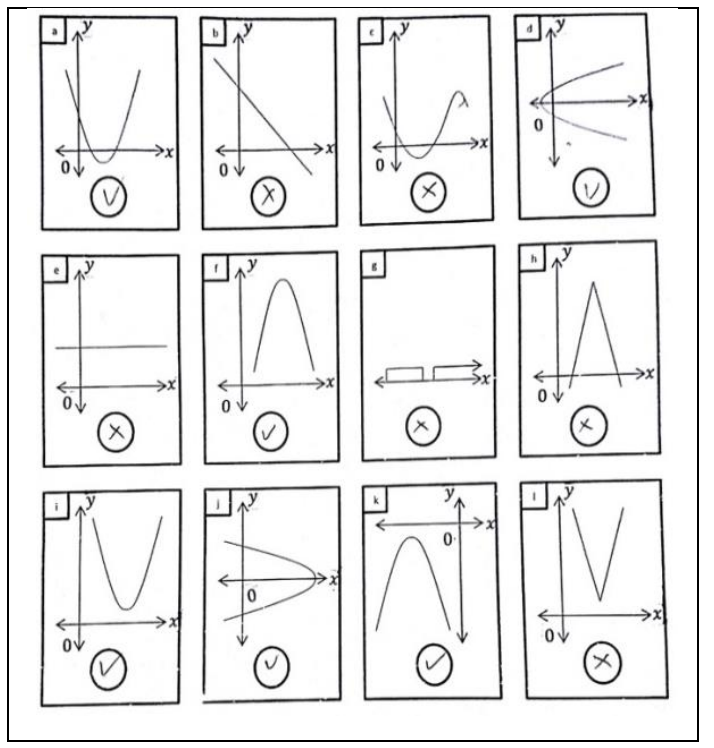

Gambar 12. Hasil identifikasi subjek akan grafik fungsi kuadrat dengan berpedoman pada bentuk parabola.

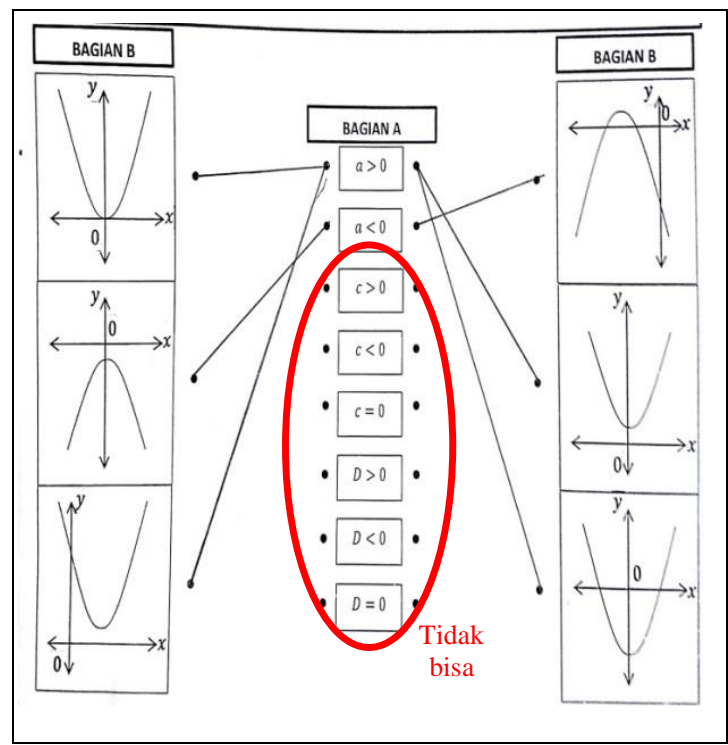

Gambar 13. Klasifikasi grafik-grafik fungsi kuadrat subjek, berdasarkan karakteristik yang disebutkan.

Berdasarkan jawaban tersebut tampak bahwa subjek tidak mampu menunjukkan grafik fungsi kuadrat yang sesuai dengan karakteristik yang dimaksudkan khususnya yaitu nilai $b, c$ dan $D$. Subjek hanya mampu menunjukkan grafik fungsi kuadrat berdasarkan nilai $a$ saja. Berdasarkan hal tersebut maka dapat disimpulkan bahwa subjek lemah dalam mengklasifikasikan grafik fungsi kuadrat berdasarkan karakteristik tertentu.

\section{Memberikan contoh dan bukan contoh dari suatu konsep.}


Berbeda dengan menyatakan ulang sebuah konsep, subjek mampu memberikan contoh dan bukan contoh dari fungsi kuadrat dan juga grafik fungsi kuadrat. Hal ini dapat dilihat dari respon siswa terhadap soal yang disajikan pada Gambar 14. Berbeda dengan subjek 1, subjek 2 tidak mampu memberikan contoh grafik fungsi kuadrat dengan kriteria khusus. Hal ini dapat dilihat pada Gambar 15. Dari 18 soal yang diberikan, subjek hanya mampu memberikan dua jawaban benar sesuai dengan karakteristik fungsi kuadrat yang diberikan yaitu karakteristik grafik fungsi kuadrat yang berhubungan dengan nilai $a$ saja.

\begin{tabular}{|c|l|l|l|}
\hline 2. b) BERIKANLAH CONTOH DAN BUKAN CONTOH FUNGSI KUADRAT, DAN GAMBARKAN CONTOH YANG BUKAN \\
\hline \multirow{3}{*}{ Mentoh Fungsi Kuadrat } & a) $y=x^{2}-1$ & b) $y=x^{2}-7 x+10$ & $\begin{array}{c}\text { Contoh Bukan Grafik Fungsi } \\
\text { Kuadrat }\end{array}$ \\
\hline & c) $y=x^{2}+2 x$ & d) $y=x^{2}$ \\
\hline \multirow{3}{*}{ Contoh Bukan Fungsi Kuadrat } & a) $y=2 x+1$ & b) $y=1$ \\
\hline & c) $y=2 x$ & d) $y=x$ & \\
\hline
\end{tabular}

Gambar 14. Respon subjek ketika diminta memberikan contoh dan bukan contoh fungsi kuadrat serta menggambarkan contoh yang bukan merupakan grafik fungsi kuadrat.

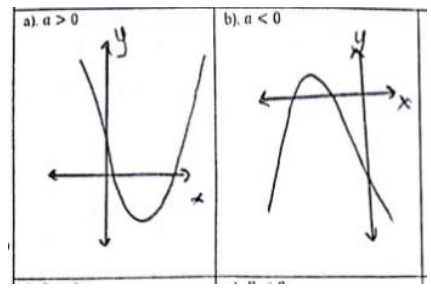

Gambar 15. Respon subjek terhadap karakteristik grafik fungsi kuadrat.

\section{Menyajikan konsep dalam berbagai bentuk representasi matematis.}

Subjek mampu menyajikan fungsi kuadrat tertentu ke dalam bentuk sketsa grafik fungsi kuadrat meskipun dengan cara yang tidak efektif. Subjek menghitung titik potong grafik dengan sumbu $x$ di dua titik, tanpa mengetahui nilai diskriminan yang kurang dari 0 yang artinya grafik fungsi kuadrat ini tidak memotong sumbu $x$ di dua titik. Contoh sketsa grafik fungsi kuadrat ditunjukkan pada Gambar 16 yang merupakan jawaban subjek ketika diminta membuat sketsa grafik fungsi $y=x^{2}-6 x+11$.

Perhatikan pernyataan di bawah ini!

a. Jika diketahui persamaan $y=x^{2}-6 x+11$, apakah persamaan tersebut sudah cukup untuk menggambarkan grafik fungsi kuadrat? Mengapa demikian?

b. Jika sudah, gambarkan grafik fungsi kuadrat tersebut!

$$
\begin{aligned}
& \text { Titik potong dengan sumbu } x, y=0 \\
& x^{2}-6 x+11=0 \\
& D=b^{2}-4 a c \\
& =(-6)^{2}-4-1,11 \\
& =36-44 \\
& =-8 \\
& x_{1}=\frac{-b+\sqrt{D}}{2 a} \cdot \frac{6+\sqrt{-8}}{2} \\
& x_{2}=\frac{-b-\sqrt{D}}{2 a}=\frac{6-\sqrt{-8}}{2} \\
& \text { Titik potong og sumbu } y, x=0 \\
& y=11 \\
& (0,11) \\
& \text { Titik puncak } \\
& x_{p}=\frac{-b}{2 a}=\frac{6}{2}=3 \\
& y_{p}=\frac{-p}{4 a}=\frac{-(-8)}{4}: 2
\end{aligned}
$$




$$
\begin{aligned}
& \text { Titik Bantu } \\
& f(2)=2^{2}-6(2)+11 \\
& =4-(2+1) \\
& =3 \\
& f(1)=1^{2}-6(1)+11 \\
& =1-6+11 \\
& =6
\end{aligned}
$$

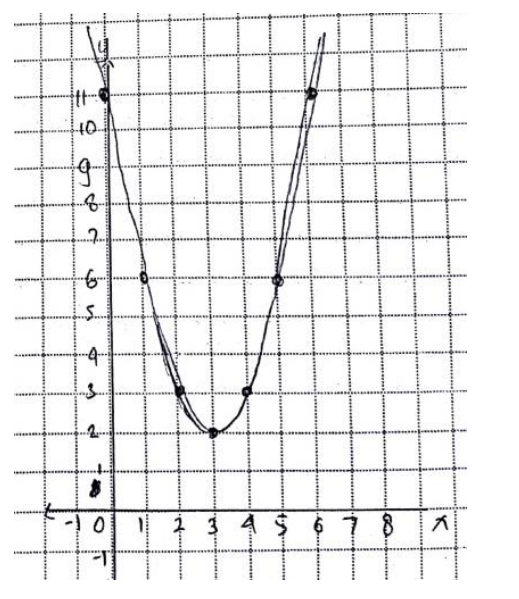

Gambar 16. Contoh sketsa grafik fungsi kuadrat dan langkah-langkah penyelesaian subjek menggambar sketsa grafik $y=x^{2}-6 x+11$

Subjek tidak mampu dalam menentukan fungsi kuadrat, subjek menggunakan persamaan $y=\left(x-x_{1}\right)\left(x-x_{2}\right)$ dan bukan $y=a\left(x-x_{1}\right)\left(x-x_{2}\right)$. Jawaban benar jika $a=1$ (Gambar 17) dan menjadi salah jika $a \neq 1$ (Gambar 18). Hal ini dapat dilihat dari Gambar 17 dan Gambar 18 yang merupakan respon subjek dalam menentukan fungsi kuadrat dari sketsa grafik fungsi kuadrat yang diberikan.

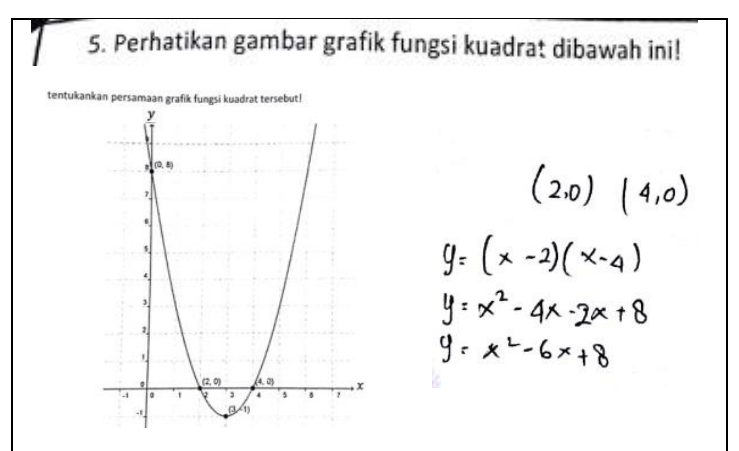

Gambar 17. Langkah dari jawaban subjek saat diminta menentukan persamaan grafik fungsi kuadrat.

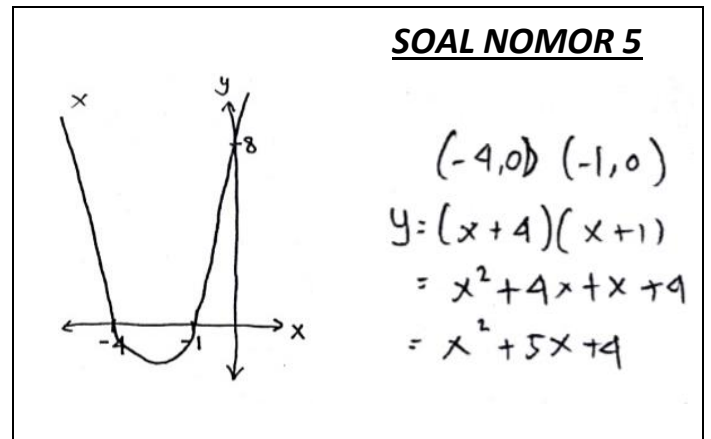

Gambar 18. Langkah dari jawaban subjek saat diminta menentukan persamaan grafik fungsi kuadrat dengan nilai $a \neq 1$, yaitu

$$
a=2 \text {. }
$$

\section{Mengembangkan Syarat Perlu Atau Syarat Cukup Dari Suatu Konsep.}

Subjek belum mampu menentukan syarat perlu dan syarat kecukupan di setiap soal yang diberikan. Contoh untuk soal nomor 4 (Gambar 16) dan 5 (Gambar 17). Ketika wawancara, subjek menyatakan bahwa informasi yang diberikan pada soal nomor 4 sudah cukup untuk digunakan dalam menyelesaikan soal. Adapun untuk soal nomor 5 , subjek hanya mampu menyatakan bahwa informasiinformasi pada sketsa grafik nomor 5 sudah dapat untuk menentukan fungsi kuadrat. Namun, ketika pengerjaan subjek masih salah dalam pengerjaannya. Hal ini dapat dilihat ketika subjek diberikan soal dengan nilai $a \neq 1$, yaitu $a=2$ (Gambar 18). 
Dengan melihat langkah-langkah penyelesaian subjek untuk soal nomor 4 (Gambar 16) dan soal nomor 5 (Gambar 17), tampak bahwa subjek kurang memahami syarat perlu dari sebuah soal. Hal ini mengakibatkan kurangnya keefektifan (pada soal nomor 4) dan dapat mengakibatkan salahnya hasil akhir (pada soal nomor 5) dalam menyelesaikan soal.

\section{Menggunakan dan Memanfaatkan Serta Memilih Prosedur Atau Operasi Tertentu.}

Ketika memilih prosedur dan menggunakan operasi tertentu, subjek berhasil menggunakan beberapa prosedur dan menggunakannya dengan benar. Untuk soal nomor 4 , ketika subjek diminta untuk menggambarkan grafik fungsi kuadrat pada fungsi $y=x^{2}-6 x+11$ subjek mampu: (1) Menentukan diskriminan, (2) Menentukan titik potong terhadap sumbu $x$ dengan rumus $x_{1,2}=\frac{-b \pm \sqrt{D}}{2 a}$ meskipun dalam kasus ini grafik fungsi kuadrat tidak memotong sumbu $y$, (3) Menentukan titik potong terhadap sumbu $y$, (4) Menentukan titik puncak $\left(x_{p}, y_{p}\right)$, dan (5) Menentukan titik bantu untuk mempermudah menggambarkan sketsa grafik fungsi kuadrat.

Berbeda dengan soal nomor 4, pada soal nomor 5 subjek tidak mampu untuk menentukan fungsi kuadrat yang diminta. Hal ini dikarenakan subjek tidak menentukan nilai $a$ terlebih dahulu dengan bantuan titik lainnya. Subjek hanya mensubstirusikan titik $(2,0)$ dan $(4,0)$ menjadi $y=(x-2)(x-$ 4) dengan hasil akhir $y=x^{2}-6 x+8$.

Berdasarkan uraian tersebut, dapat diketahui bahwa 6 aspek kurang terpenuhi dengan baik, sehingga untuk aspek yang ke tujuh subjek hanya mampu menggambar sketsa grafik fungsi kuadrat dengan baik dan benar. Selebihnya, subjek 2 kebingungan untuk menyelesaikan soal dikarenakan kurangnya pemahaman konsep grafik fungsi kuadrat, seperti menentukan fungsi kuadrat jika diketahui titik puncak grafik dengan bantuan satu titik lain pada grafik dan menentukan fungsi kuadrat jika diketahui titik potong terhadap sumbu $x$ dengan bantuan satu titik lain pada grafik. Hal ini dibuktikan dengan gagalnya subjek dalam menyelesaikan soal pendahuluan yang mana subjek gagal mengaplikasikan konsep dan algoritma pada pemecahan masalah.

\section{Subjek 3}

\section{Menyatakan ulang sebuah konsep.}

Subjek mampu menyebutkan bahwa bentuk umum dari fungsi kuadrat adalah $y=a x^{2}+b x+c$, subjek hanya menyebutkan bahwa grafik fungsi kuadrat berbentuk melengkung. Subjek juga tidak menekankan syarat khusus fungsi kuadrat yaitu $a \neq 0$ dan pangkat tertinggi bagi variabel $x$ adalah dua. Subjek mampu menyebutkan karakteristik grafik fungsi kuadrat, namun tidak semua karakteristik yang subjek sebutkan benar benar. Karakteristik yang berhubungan dengan nilai a. Subjek menyebutkan bahwa "grafik akan terbuka ke atas, jika nilai $a>0$, sedangkan grafik akan terbuka ke bawah, jika nilai $a<0$. Karakteristik lainnya yaitu yang berhubungan dengan nilai $b$, jika $b>0$ maka grafik akan berada di sebelah kanan sumbu $y$, jika $b<0$ maka grafik akan berada di sebelah kiri sumbu $y$, dan jika $b=0$, maka grafik akan berada di tengah-tengah sumbu $y$. Akan tetapi karakteristik yang berhubungan dengan nilai $b$ ini hanya berlaku ketika $a>0$. Sebaliknya, jika $a<0$ 
maka grafik dengan nilai $b<0$ akan berada di sebelah kanan sumbu $y$, dan jika $b>0$ maka grafik akan berada di sebelah kiri sumbu $y$. Oleh karena itu, Subjek salah salah menyebutkan karakteristik yang berhubungan dengan nilai $b$ karena posisi grafik (di sebelah kanan atau di sebelah kiri) itu tergantung dengan nilai $a$. Karakteristik yang lainnya yaitu yang berhubungan dengan nilai $c$, subjek menyebutkan bahwa, jika $c>0$ maka jika titik puncak grafik berada di atas sumbu $x$, jika $x<0$ maka titik puncak grafik berada di bawah sumbu $x$, dan jika $c=0$ maka titik puncak grafik berada di $(0,0)$. Karakteristik tersebut salah, karena karakteristik yang berhubungan dengan nilai $c$ ini berhubungan dengan titik potong sumbu $y$. Dimana jika $c>0$ maka grafik akan memotong sumbu $y$ positif, jika $c<0$ maka grafik akan memotong sumbu $y$ negatif, dan jika $c=0$ maka grafik akan memotong di $y=0$. Subjek juga menyebutkan karakteristik yang berhubungan dengan nilai $D$ atau diskriminan. Subjek menyebutkan bahwa jika nilai $D>0$ maka grafik fungsi akan memotong sumbu $x$ didua titik, jika nilai $D<0$ maka grafik tidak akan memotong sumbu $x$, dan jika nilai $D=0$ maka grafik akan meninggung sumbu $x$.

Berdasarkan hal tersebut dapat disimpulkan bahwa subjek 3 belum sepenuhnya mampu menyatakan ulang sebuah konsep grafik fungsi kuadrat. Subjek dapat menyebutkan karakteristik grafik fungsi kuadrat berdasarkan nilai $b, c$ dan $D$ (diskriminan), meski terdapat beberapa konsep yang tidak tepat.

\section{Mengklasifikasikan objek menurut sifat-sifat tertentu sesuai dengan konsepnya.}

Subjek mampu mengidentifikasi gambar grafik fungsi kuadrat dan bukan grafik fungsi kuadrat dengan berpedoman pada konsep bahwa grafik fungsi kuadrat berbentuk parabola. Hal ini dapat dilihat pada jawaban subjek untuk soal nomor 2 yang disajikan pada Gambar 19. Tidak hanya mampu mengidentifikasi yang merupakan grafik fungsi kuadrat atau bukan, subjek juga mampu mengklasifikasikan grafik-grafik fungsi kuadrat berdasarkan karakteristik yang disebutkan Gambar 20. Akan tetapi tidak semua jawaban yang subjek berikan sepenuhnya benar, hal ini tampak pada grafik fungsi kuadrat Gambar 20 (lingkaran merah) yang seharusnya mempunyai nilai $c<0$. Hal ini terjadi karena subjek 3 salah akan konsep karakteristik yang berhubungan dengan nilai $c$, dimana karakteristik nilai $c$ berhubungan dengan titik potong terhadap sumbu $y$ dan bukan berhubungan dengan letak titik puncak. 


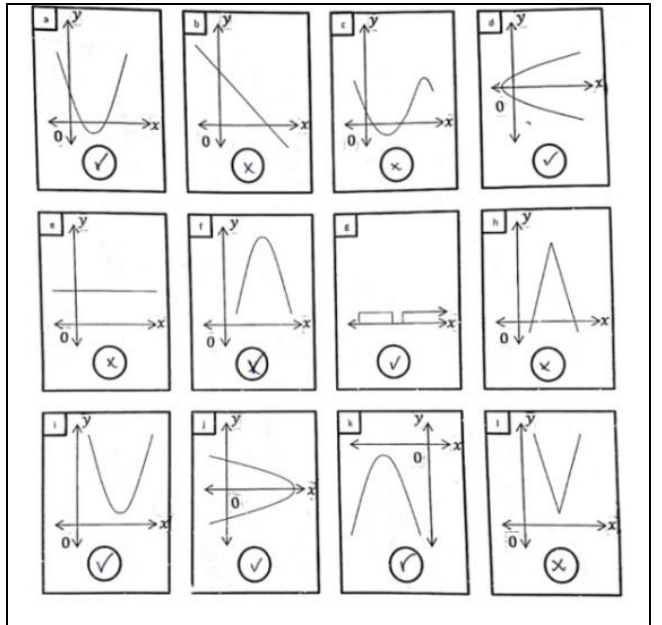

Gambar 19. Hasil identifikasi subjek akan grafik fungsi kuadrat dengan berpedoman pada bentuk parabola.

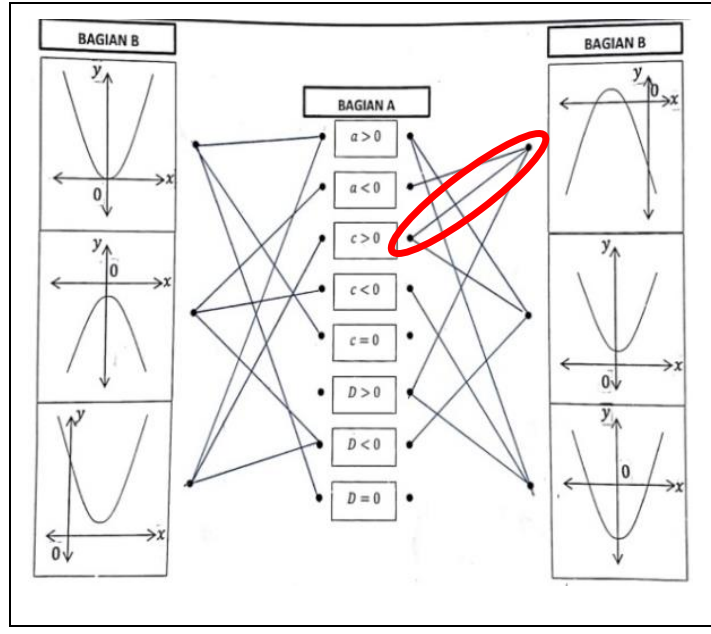

Gambar 20. Respon subjek terhadap

karakteristik grafik fungsi kuadrat.

\section{Memberikan contoh dan bukan contoh dari suatu konsep.}

Berbeda dengan menyatakan ulang sebuah konsep, subjek mampu memberikan contoh dan bukan contoh dari fungsi kuadrat dan juga grafik fungsi kuadrat. Hal ini dapat dilihat dari respon siswa terhadap soal yang disajikan pada Gambar 21.

\begin{tabular}{|}
\begin{tabular}{|c|l|l|l|}
\hline 2. b) BERIKANLAH CONTOH DAN BUKAN CONTOH FUNGSI KUADRAT, DAN GAMBARKAN CONTOH YANG BUKAN \\
MERUPAKAN GRAFIK FUNGSI KUADRAT!! \\
\hline \multirow{3}{*}{ Contoh Fungsi Kuadrat } & a) $y=x^{2}+8 x+16$ & b) $y=x^{2}+3 x+21$ & $\begin{array}{c}\text { Contoh Bukan Grafik Fungsi } \\
\text { Kuadrat }\end{array}$ \\
\hline & c) $y=x^{2}+4 x+12$ & d) $y=x^{2}+7 x+28$. \\
\hline \multirow{3}{*}{ Contoh Bukan Fungsi Kuadrat } & a) $y=4 x+8$ & b) $y=5 x+20$ \\
\hline & c) $y=3 x+9$ & d) $y=7 x+28$ & \\
\hline
\end{tabular}
\end{tabular}

Gambar 21. Respon subjek ketika diminta memberikan contoh dan bukan contoh fungsi kuadrat serta menggambarkan contoh yang bukan merupakan grafik fungsi kuadrat.

Sama halnya dengan subjek 2, subjek 3 tidak dapat memberikan contoh grafik fungsi kuadrat dengan kriteria khusus dengan sepenuhnya benar. Hal ini dapat dilihat pada Gambar 22. Dari 18 soal yang diberikan, subjek hanya mampu memberikan sebelas jawaban benar sesuai dengan karakteristik fungsi kuadrat yang diberikan. Hal ini dapat terjadi karena subjek 3 tidak sepenuhnya mengetahui konsep karakteristik grafik fungsi kuadrat yang berhubungan dengan nilai $b$, serta subjek 3 salah akan konsep karakteristik grafik fungsi kuadrat yang berhubungan dengan nilai $c$. 


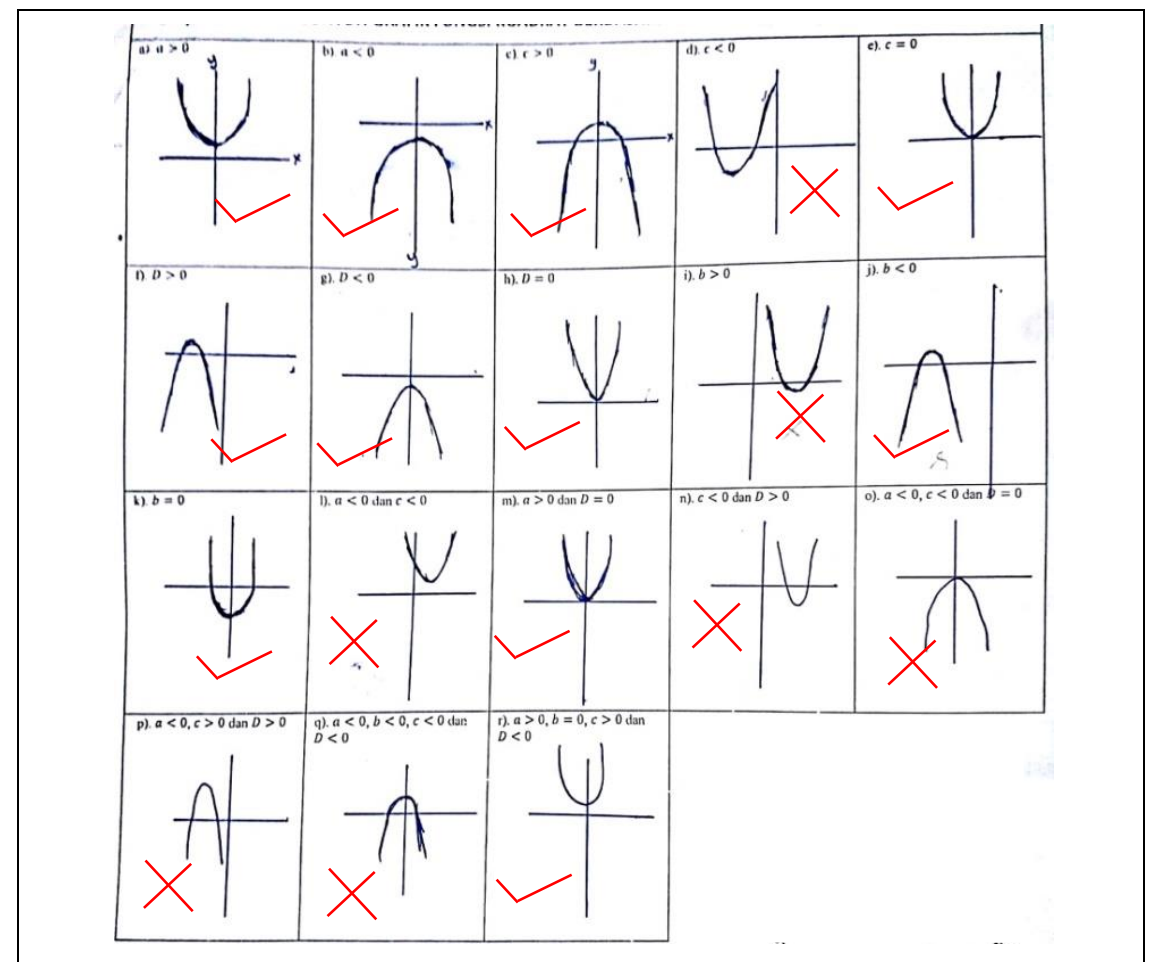

Gambar 22. Jawaban subjek ketika diminta memberikan contoh grafik fungsi kuadrat berdasarkan karakteristiknya.

\section{Menyajikan Konsep Dalam Berbagai Bentuk Representasi Matematis.}

Pada soal nomor 4, subjek tidak mampu menyajikan fungsi kuadrat tertentu ke dalam bentuk sketsa grafik fungsi kuadrat. Subjek kesulitan untuk mencari akar-akar dari fungsi $y=x^{2}-6 x+11$ untuk menentukan dua titik potong grafik terhadap sumbu $x$. Sedangkan nilai $D$ dari fungsi $y=x^{2}-$ $6 x+11$ adalah $D=-8$ yang artinya jika nilai $D<0$, maka grafik tidak akan memotong sumbu $x$. Dikarenakan subjek tidak menyadari akan hal ini, subjek merasa kesulitan dan tidak dapat menggambarkan sketsa grafik fungsi $y=x^{2}-6 x+11$ yang diminta.

Subjek juga tidak mampu dalam menentukan fungsi kuadrat, subjek menggunakan persamaan $y=\left(x-x_{1}\right)\left(x-x_{2}\right)$ dan bukan $y=a\left(x-x_{1}\right)\left(x-x_{2}\right)$. Jawaban benar jika $a=1$ (Gambar 23) dan menjadi salah jika $a \neq 1$ (Gambar 24). Hal ini dapat dilihat dari Gambar 23 dan Gambar 24 yang merupakan respon subjek dalam menentukan fungsi kuadrat dari sketsa grafik fungsi kuadrat yang diberikan.
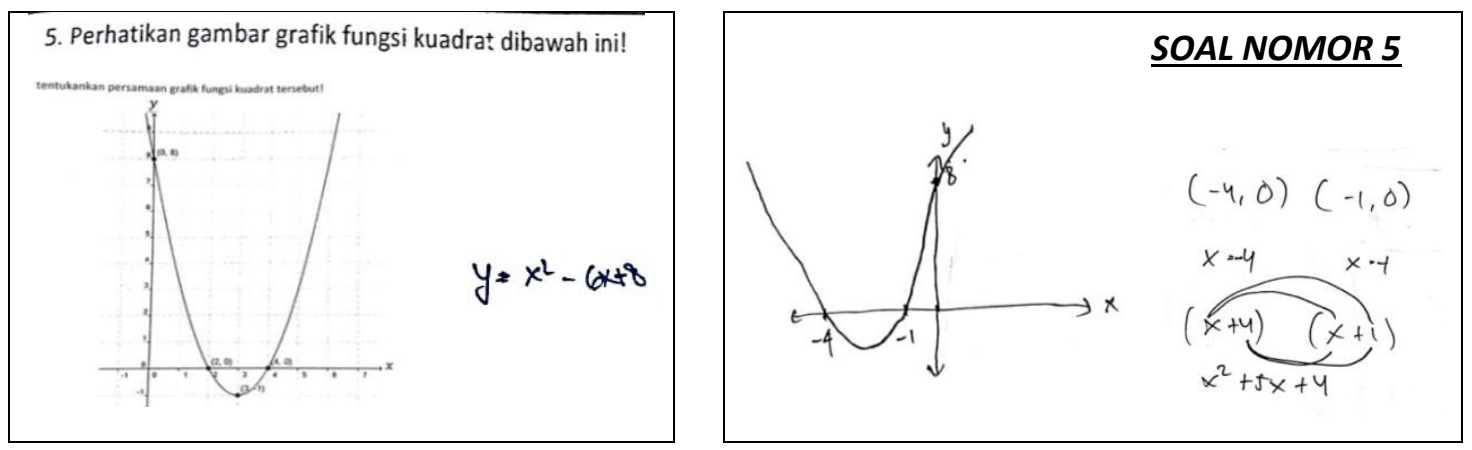


\author{
Gambar 23. Jawaban subjek saat \\ diminta menentukan persamaan grafik \\ fungsi kuadrat.
}

\footnotetext{
Gambar 24. Langkah dari jawaban subjek

saat diminta menentukan persamaan grafik

fungsi kuadrat dengan nilai $a \neq 1$, yaitu

$a=2$.
}

\section{Mengembangkan Syarat Perlu atau Syarat Cukup dari Suatu Konsep.}

Subjek belum mampu menentukan syarat perlu dan syarat kecukupan disetiap soal yang diberikan. Contoh untuk soal nomor 4 dan 5. Ketika wawancara, subjek menyatakan bahwa informasi yang diberikan pada soal nomor 4 sudah cukup untuk digunakan dalam menyelesaikan soal. Akan tetapi subjek 3 tidak mampu memanfaatkan syarat perlu dan syarat kecukupan untuk menyelesaikan soal nomor 4 ini. Adapun untuk soal nomor 5, subjek hanya mampu menyatakan bahwa informasiinformasi pada sketsa grafik nomor 5 sudah dapat untuk menentukan fungsi kuadrat. Namun, ketika pengerjaan subjek masih salah dalam menyelesaikan soal nomor 5. Hal ini dapat dilihat ketika subjek diberikan soal dengan nilai $a \neq 1$, yaitu $a=2$ Gambar 24 .

Dengan melihat langkah-langkah penyelesaian subjek untuk soal nomor 5 (Gambar 23), tampak bahwa subjek kurang memahami syarat perlu dari sebuah soal. Hal ini mengakibatkan gagalnya subjek dalam menyelesaikan soal nomor 4 dan dapat mengakibatkan salahnya hasil akhir (soal nomor 5) dalam menyelesaikan soal.

\section{Menggunakan dan memanfaatkan serta memilih prosedur atau operasi tertentu.}

Ketika memilih prosedur dan menggunakan operasi tertentu, subjek belum berhasil menggunakan beberapa prosedur dan menggunakannya. Untuk soal nomor 4 , ketika subjek diminta untuk menggambarkan grafik fungsi kuadrat pada fungsi $y=x^{2}-6 x+11$ subjek hanya mampu menyebutkan rumus untuk menentukan titik puncak grafik fungsi kuadrat yaitu $\left(X_{p}, Y_{p}\right)=$ $\left(-\frac{b}{2 a},-\frac{D}{4 a}\right)$. Selebihnya ketika subjek menghitung, subjek salah mensubstitusi fungsi kedalam persamaan.

Berbeda dengan soal nomor 4, pada soal nomor 5 subjek tidak mampu untuk menentukan fungsi kuadrat yang diminta. Hal ini dikarenakan subjek tidak menentukan nilai $a$ terlebih dahulu dengan bantuan titik lainnya. Subjek hanya mensubstirusikan titik $(2,0)$ dan $(4,0)$ menjadi $y=(x-2)(x-$ 4) dengan hasil akhir $y=x^{2}-6 x+8$.

Berdasarkan uraian tersebut, dapat diketahui bahwa 6 aspek kurang dipenuhi subjek dengan baik, hal ini mengakibatkan gagalnya subjek 3 dalam menggambar sketsa grafik fungsi kuadrat pada aspek yang ke tujuh. Hal ini dibuktikan dengan gagalnya subjek dalam menyelesaikan soal pendahuluan yang mana subjek gagal mengaplikasikan konsep dan algoritma pada pemecahan masalah. Selebihnya, subjek 3 gagal untuk menyelesaikan soal dikarenakan kurangnya pemahaman konsep grafik fungsi kuadrat, seperti subjek 3 tidak menyadari akan nilai $D<0$ pada soal nomor 4 sehingga subjek kesulitan dalam menggambarkan sketsa grafik fungsi kuadrat, menentukan fungsi kuadrat jika 
diketahui titik puncak grafik dengan bantuan satu titik lain pada grafik dan menentukan fungsi kuadrat jika diketahui titik potong terhadap sumbu $x$ dengan bantuan satu titik lain pada grafik.

Ketiga subjek memiliki kemampuan yang berbeda dalam menyatakan ulang sebuah konsep. Ketiga subjek mampu menyatakan bahwa grafik fungsi kuadrat merupakan representatif dari fungsi kuadrat $f(x)=a x^{2}+b x+c$. Jika subjek $1 \& 2$ menyebutkan bahwa grafik berbentuk parabola, sedangkan subjek 3 menyebutkan grafik berbentuk melengkung. Tidak hanya itu subjek 1 mampu menyatakan ulang karakteristik grafik fungsi kuadrat berdasarkan nilai koefisien $a, b, c$ dan $D$ (Diskriminan), sedangkan subjek 2 hanya mampu menyatakan ulang konsep karakteristik berdasarkan nilai koefisien a saja. Berbeda dengan subjek 3, subjek 3 hanya mampu menyatakan ulang konsep karakteristik berdasarkan nilai koefisien $a$ dan $D$ (Deskriminan), selebihnya subjek 3 menjawab salah konsep karakteristik berdasarkan nilai $c$ dan $b$. Ketiganya tidak menyebutkan syarat koefisien $a \neq 0$ dan pangkat tertinggi fungsi kuadrat adalah 2.

Adapun hasil pembahasan dari kemampuan ketiga subjek pada tahap yang kedua yaitu subjek 1 belum mengenali bentuk umum fungsi kuadrat dalam peubah $y$, yaitu $x=f(y)=a y^{2}+b y+c$ subjek belum berhasil menggolongkan mana yang merupakan grafik fungsi kuadrat dan mana yang bukan merupakan grafik fungsi kuadrat. Pada tahap yang kedua subjek 2 berhasil mengklasifikasikan objek-objek dipenuhi tidaknya persyaratan yang membentuk suatu konsep, dimana subjek 2 diminta untuk mengklasifikasikan sketsa yang merupakan grafik fungsi kuadrat dan yang bukan merupakan grafik fungsi kuadrat. Subjek juga mampu memberikan contoh dan bukan contoh fungsi kuadrat dan juga memberikan contoh sketsa grafik yang bukan merupakan sketsa grafik fungsi kuadrat. Pada saat mengklasifikasikan objek-objek berdasarkan dipenuhi tidaknya suatu konsep, subjek 3 mampu mengidentifikasi gambar grafik fungsi kuadrat dan bukan grafik fungsi kuadrat dengan berpedoman pada konsep bahwa grafik fungsi kuadrat berbentuk parabola. Ketiga subjek mampu memberikan contoh dan bukan contoh fungsi kuadrat dengan benar. Ketiga subjek juga mampu memberikan bukan contoh dari sketsa grafik fungsi kuadrat.

Ketiga subjek juga mempunyai kemampuan yang berbeda dalam menyajikan konsep dalam berbagai bentuk representasi matematis. Subjek 1 mampu untuk menyelesaikan soal dengan runtut dan benar Gambar 10 dan Gambar 11, hal ini dikarenakan subjek 1 mampu menyesuaikan diri dari menyatakan ulang sebuah konsep dengan berbagai contoh dan bukan contoh dari sebuah konsep grafik fungsi kuadrat, menyesuaikan diri dari menyatakan ulang sebuah konsep dengan mengklasifikasikan objek terhadap pemahaman konsep grafik fungsi kuadrat, adapun dari sketsa grafik fungsi kuadrat ke fungsi kuadrat dan dari fungsi kuadrat ke sketsa grafik fungsi kuadrat. Subjek 2 hanya mampu menyajikan konsep ke dalam bentuk representatif pada nomor 4 Gambar 16 saja. Pada tahap yang ini subjek 2 dan 3 juga tidak mampu dalam menentukan fungsi kuadrat pada soal nomor 5, subjek menggunakan persamaan $y=\left(x-x_{1}\right)\left(x-x_{2}\right)$ dan bukan $y=a\left(x-x_{1}\right)\left(x-x_{2}\right)$. 
Jawaban benar jika $a=1$ dan menjadi salah jika $a \neq 1$. Hal ini dikarenakan subjek 2 dan 3 lemah dalam menyatakan ulang sebuah konsep grafik fungsi kuadrat.

Pada tahap yang kelima dan keenam yaitu mengembangkan syarat perlu dan syarat cukup dari suatu konsep dan menggunakan, memanfaatkan serta memilih prosedur atau operasi tertentu, subjek 1 mampu mengembangkannya konsep grafik fungsi kuadrat dan mampu menggunakan, memanfaatkan serta memilih prosedur sehingga subjek 1 mampu menyelesaikan soal nomor 4 dan nomor 5 dengan benar. Berbeda dengan subjek 1, subjek 2 dan 3 belum bisa melakukan tahap kelima dan keenam dengan baik. Hal ini terlihat pada soal nomor 5 dimana subjek 2 dan 3 tidak menentukan nilai $a$ terlebih dahulu untuk menentukan fungsi kuadrat, ini akan berakibat fatal jika soal yang diberikan mempunyai nilai $a \neq 1$.

\section{KESIMPULAN}

Penelitian ini digunakan untuk menggali dan mendeskripsikan tentang analisis pemahaman konsep siswa kelas X menggunakan indikator pemahaman konsep matematika (Kusumawati, 2010: 28-29). Hasil yang diperoleh melalui tes uraian dan wawancara terhadap ketiga subjek bahwa masih terdapatnya konsep-konsep grafik fungsi kuadrat yang tidak sesuai dari ketiga subjek. Subjek 1, hanya mengenali bentuk grafik fungsi kuadrat yang membuka ke atas dan ke bawah saja, selebihnya yaitu grafik fungsi kuadrat yang membuka ke kanan dan ke kiri subjek menggolongkannya sebagai bukan grafik fungsi kuadrat. Hal ini tidak terlalu berdampak pada konsep grafik fungsi kuadrat lainnya. Selanjutnya subjek 2, ia hanya mengenali karakteristik grafik fungsi kuadrat yang berhubungan dengan nilai $a$ saja, selebihnya yaitu karakteristik yang berhubungan dengan nilai $b, c$ dan $D$ (diskriminan) subjek tidak mengenalinya. Kurangnya mengenali karakteristik grafik fungsi kuadrat sedikit berdampak pada konsep grafik fungsi lainnya. Hal ini dibuktikan ketidakmampuannya subjek 2 dalam menentukan persamaan parabola yang kedua. Subjek yang terakhir yaitu subjek 3, ia salah menerapkan beberapa konsep pada soal nomor 6 yang mengakibatkan ia tidak dapat menyelesaikan soal dengan benar. Tingkat pemahaman konsep mempengaruhi keberhasilan siswa dalam menyelesaikan permasalahan matematika. Berdasarkan hasil tersebut, maka disarankan bagi guru untuk menekankan pemahaman konsep grafik fungsi kuadrat ini sebelum pelatihan pemecahan masalah matematika. Hal ini selaras dengan Putri (2020) yang menyatakan bahwa belajar matematika akan lebih berhasil jika proses pembelajaran diarahkan pada konsep dan struktur dalam pokok bahasan yang sedang diajarkan.

Mengingat pentingnya pemahaman semua konsep dalam matematika, siswa diharapkan menguasai Kemampuan Berpikir Tingkat Tinggi (HOTS). HOTS sangat penting bagi setiap siswa karena HOTS adalah keterampilan yang meliputi kemampuan seseorang untuk berpikir secara kritis, logis, reflektif, metakognitif, dan kreatif (Zulfah et al, 2019). HOTS merupakan istilah yang sering disebut dalam era pendidikan abad ke-21 karena dianggap sebagai salah satu keterampilan abad ke-21. 


\section{DAFTAR PUSTAKA}

Ayu, Novita. D, Panco S, dan Getut P. (2018). Analisis Pemahaman Konsep Matematika Siswa dalam Menyelesaikan Soal Faktorisasi Suku Aljabar Berdasarkan Kesulitan Belajar Faktor Intelektual Siswa pada Kelas VIII B SMP N 8 Surakarta Tahun Ajaran 2016/2017. Jurnal Phenomenon, 8(1), 26-35.

Fitriastika, Dian. (2014). Analisis Pemahaman Tentang Fungsi Kuadrat Berdasarkan Teor APOS Pada Siswa Kelas X Jurusan Permesinan SMK Negeri 2 Salatiga [Skripsi]. Salatiga (ID): Universitas Kristen Satya Wacana.

Hanifah., Agung PA. (2018). Analisis Pemahaman Konsep Matematika Mahasiswa dalam Menyelesaikan Soal Teori Grup. Journal of Medives : Journal of Mathematics Education IKIP Veteran Semarang, 2(2), 235-244.

Idris, N. (2009). Enhancing students' understanding in calculus trough writing. International Electronic Jurnal of Mathematics Education, 4(1), 36-55.

Kadir, Kamaliyah., Sri M., Tjang DC. (2018). Penerapan Langkah-langkah Pembelajaran Van Hiele Berbantuan Media Manipulatif sebagai Upaya Meningkatkan Pemahaman Konsep Segiempat Siswa. Jurnal Pendidikan: Teori, Penelitian dan Pengembangan, 3(1), 134-145.

Kesumawati, N. (2010). Peningkatan Kemampuan Pemahaman, Pemecahan Masalah, dan Disposisi Matematis Siswa Melalui Pendekatan Pendidikan Matematika Realistik. Disertai PPs UPI Bandung: tidak dipublikasikan.

Mustofa, A. A., \& Tuhartoo, M. S. (2018). Efektifitas Penerapan Model Pembelajarran Kooperatif Tipe Numbered Head Together (NHT) dengan Time Tokens ditinjau dari Pemahaman Konsep Matematika dan Keterampilan Sosial Siswa Kelas VII SMP. Jurnal Pendidikan Matematika$S 1,7(2), 48-57$.

Putri, Yunia Eka. (2020) Perbandingan PBL dan DL Terhadap Pemahaman Konseptual Siswa Kelas XI Ditinjau dari Motivasi Belajar. Jurnal Cendekia: Jurnal Pendidikan Matematika, 4 (1), 40 52 .

Shadiq, F. dan Nur Amini Mustajab. (2011). Penerapan Teori Belajar dalam Pembelajaran Matematika di SD. Yogyakarta: Kementrian Pendidikan Nasional Badan Pengembangan Sumber Daya Manusia Pendidikan dan Penjamin Mutu Pendidikan.

Suraji, S., Maimunah, M., \& Saragih, S. (2018). Analisis Kemampuan Pemahaman Konsep Matematis dan Kemampuan Pemecahan Masalah Matematis Siswa SMP pada Materi Sistem Persamaan Linear Dua Variabel (SPLDV). Suska Journal of Mathematics Education, 4(1), 9-16.

Zirbel, E. (2006). Teaching to Promote Deep Understanding and Instigate Conceptual Change. Bulletin of the American Astronomical Society, 38, 1220.

Zulfah, dkk. (2019). Development of Open-Ended Based Mathematics Problem to Measure High- 
Level Thinking Ability. Journal of Physics: Conference Series.

Zulfah et al 2019 J. Phys.: Conf. Ser. 1315012047

Zulkardi. (2003). Pendidikan Matematika di Indonesia : Beberapa Permasalahan dan Upaya Penyelesaiannya. Palembang: Unsri. 